\begin{tabular}{|c|c|c|c|}
\hline & $\begin{array}{c}\text { International Journal of Current Research in } \\
\text { Biosciences and Plant Biology }\end{array}$ \\
\hline EXCELLENT \\
PUBLISHERS
\end{tabular}

\title{
Scaling-up of Neem (Azadirachta indica A. Juss) Cultivation in Agroforestry for Entrepreneurship and Economic Strengthening of Rural Community of India
}

\author{
Arvind Bijalwan $^{1} *$, Manmohan J. R. Dobriyal ${ }^{2}$, Tarun Kumar Thakur ${ }^{3}$, Pooja Verma ${ }^{1}$ \\ and Shalini Singh ${ }^{1}$
}

${ }^{1}$ Indian Institute of Forest management (IIFM), P.O. Box-357, Nehru Nagar, Bhopal-462 003, Madhya Pradesh, India

${ }^{2}$ Department of Silviculture and Agroforestry, College of Forestry, Navsari Agricultural University, Navsari - 396 450, Gujarat, India

${ }^{3}$ Department of Environmental Science, Indira Gandhi National Tribal University (IGNTU), Amarkantak, Madhya Pradesh, India

*Corresponding author.

\begin{tabular}{|c|c|}
\hline Abstract & Article Info \\
\hline \multirow{12}{*}{$\begin{array}{l}\text { Neem (Azadirachta indica A. Juss) is a unique tree with its great religious, medicinal, } \\
\text { ornamental and multifunctional values. Old Indian literature viz. Atharava Veda, } \\
\text { Upanishda, Amarkosha, Ghrayasutra, Ayurveda etc. mention neem tree as "Sarva Roga } \\
\text { Nivarini" means medicine to cure all the diseases and United Nations declared it as "Tree } \\
\text { of } 21^{\text {st }} \text { century". In India the Neem tree is household name and well distributed in rural as } \\
\text { well as urban landscape but its promotion as a agroforestry tree either block, strip or } \\
\text { boundary planting on farmland is limited. The hardy and multipurpose neem tree holds } \\
\text { tremendous potential in sustainable farming systems across the world. Different } \\
\text { agroforestry research has been carried out for intercropping with neem like sorghum, } \\
\text { black gram, wheat, chickpea, groundnut, pearl millet, cotton, sorghum, horsegram, } \\
\text { mungbean, cowpea, vegetables, grasses etc. under agri-silviculture, agri-silvi-horticulture, } \\
\text { silvipastoral system and shelter belts/wind breaks etc. Besides this it has been also } \\
\text { promoted for afforestation in farm and social forestry plantations and by NOVOD board } \\
\text { for seed oil but this mission has not yielded marked change in large scale adoption by } \\
\text { farming community. Inspite of such a highly bio-prospected species from datoon (Natural } \\
\text { toothbrush) to contraceptive and neem coated urea, it has not been enterprised for rural } \\
\text { economy. There is need to scaling up the neem tree cultivation on farm or agroforestry for } \\
\text { entrepreneurship and economic strengthening of rural community of India. }\end{array}$} & $\begin{array}{l}\text { Accepted: } 02 \text { January } 2017 \\
\text { Available Online: 06 January } 2017\end{array}$ \\
\hline & Keywords \\
\hline & Agrisilviculture \\
\hline & Agroforestry \\
\hline & Entrepreneurship \\
\hline & Multipurpose \\
\hline & Neem \\
\hline & \\
\hline & \\
\hline & \\
\hline & \\
\hline & \\
\hline
\end{tabular}

\section{Introduction}

Azadirachta indica A. Juss commonly known as neem belongs to family Meliaceae is a unique tree with its great religious, medicinal, ornamental and multifunctional values. Its origin is believed to be Upper Myanmar in Burma (Brandis, 1906), in the forest of Siwaliks, India (Troup, 1921). Neem has naturalized in different parts of Maharashtra, Madhya Pradesh including various regions of India [apart from very high 
and cold areas, (Sidhu, 1995)] as a farm tree nearby human habitation on the bunds of agricultural fields. It is intermixed with the lifestyle of Indian people that they prefer it to grow near house-yards, paths and around worshipping places (Luna, 1996). Neem is medium to large size, tree with spherical crown of bright green dense foliage and a strong stem (Luna, 1996). It is the most versatile and multipurpose tree with immense potential in the tropical region (Girish and Bhat, 2008). From the primeval times, it has been a noteworthy common plant species in India due to its multifunctional uses like medicinal uses, biofertilizer, fumigant, bio pesticides, oilseed, cattle feed with various ecological and environmental benefits (Chinnamani, 1993; Lokanadhan et al., 2012). The description of Neem tree is also available in the old Indian literature viz. Atharava Veda, Upanishad, Amarkosha, Ghrayasutra. In Ayurveda neem tree is said "Sarva Roga Nivarini" means medicine to cure all the diseases. Considering its value the Neem has declared by the United Nations as "Tree of $21^{\text {st }}$ century" (Neem foundation, http://www.neemfoundation.org). In India, the Neem is popular with various names as Divine Tree, Natures Drugstore, and Panacea for all diseases, Life giving Tree, Village Pharmacy, etc. Its wood has become increasingly valued for its use in furniture production and flowers bee forage for a tasty honey. Neem shoots, leaves, and flowers are also consumed in a soup-like dish or fried, seasoned, and served as an appetizer. In India research on neem oil and neem cake began in the 1920s at the Indian Institute of Science in Bangalore followed by in 1960, neem's insecticidal properties at the Indian Agricultural Research Institute (IARI) in Delhi which credited for controlling locusts by spraying with neem kernel extract (Kumar, 2015). Neem has unique environmental significance can tolerate very high levels of pollution (Kumar et al., 2013) and has the capacity to reclaim relatively higher quantities of lead and absorb other pollutants like particulate dust, $\mathrm{CO}_{2}$, oxides of sulphur and nitrogen.

NEERI, 1996 indicated that Neem tree is one of the most suitable species for checking urban pollution in industrial locations and it has prospective in green belt development in hot spots with known history of high air pollution. Neem has comparatively high efficiency of $\mathrm{CO}_{2}$ fixation. It can fix more than 14 micro mole of $\mathrm{CO}_{2}$ per $\mathrm{m}^{2}$ per Sec. (http://www.neemfoundation.org/ greening-india-with-neem/). The Neem tree is globally being acknowledged as the most valuable tree in terms of commercial and industrial potential (Blackwell, 1997;
Isman, 2004). Though it is the de-facto National Tree of India but the seriousness of neem research in western world began early by organising first and second international conferences on neem in 1980 and 1983 in Germany and in Kenya in 1986 and later fourth in Bangalore, India but all these reflects the utilisation aspect of neem. Even in 1993 onwards First world neem congress held in Bangalore and recently 6th World Neem Conference which was held in Nagpur in 2012 also predominantly focused was on utilisation rather promotion its cultivation and development value chain mechanism through agroforestry.

Fragrance and Flavour Development Centre (FFDC), Kannauj, 1998 opened a neem centre at Jhalawar, Rajasthan which now closed due to lack to proper functional and professional mechanism in government institutes. It's known that Emperor Ashoka, in the 3rd century Before Christ, planted Neem along the road highway along with Tamarindus indica and Madhuca latifolia. Neem plantations in India are restricted to village homesteads and farmlands. Organised plantations are rare. Using the tissue culture technique for neem (Zypman et al., 1996), a large number of plants would be available for agroforestry. In 1996, the proposal is to integrate Neem in Forestry and Social Forestry Programmes on a National Scale. Similarly, National Oilseeds and Vegetable Oils Development (NOVOD) Board from 1999 - 2002 had National Neem Network to implement a National Programme on Neem and to promote Neem Plantation on a larger scale by identifying, raising and providing superior germplasm of neem.

\section{Azadirachta indica (Neem) in agroforestry}

Neem is commonly growing on the bunds of agriculture field traditionally (Depommier, 2003) thus, considered to be a one of the important multifunctional agroforestry tree (Pandey and Tarafdar, 2004). Basically agroforestry is a land use system that integrates trees, crops and animals in an approach that is scientifically sound, ecologically desirable, practically feasible and socially suitable to the farmers (Nair, 1979; Nair, 1985). The tree component is preferred in agroforestry system according to local requirement with multiple products and easily marketable with good economic value (Radwanski and Wickens, 1981; Bohra et al., 2016). Adaptation of agroforestry on all kinds of waste lands in the country and incorporation of multipurpose trees (MPTs) is already in practiced in all cropping/farming system 
(Chuntanaparb and Ranganathan, 1990; Mutanal et al., 2010). It is an ideal option to reclaim and to enhance the productivity of wasteland by planting the MPTs like Neem which re-establishes the soil fertility and richness (Drechsel et al., 1991) and also increases the production of others herbs and shrubs. The good coppicing ability of Neem, as well as low mortality makes this tree favourable for use in agroforestry systems (Chaturvedi, 1993).

Neem is best ideotype tree species for agroforestry systems as it posses both multipurpose and multifunctional characteristics. It maintains the temperature; humidity of soil i.e. works for soil moisture conservation (Gupta, 1994). The neem tree lessens the risk to the failure of intercrops in rainfed condition by upholding the moisture and nourishing the crop. Keeping the multipurpose nature of neem tree as an adaptable tree species, this tree can be denoted as "agroforestry tree of India" due to its wide adaptableness, manifold scope and moreover as an alternate income source to the villagers/rural poor. Neem trees in the farmlands is beneficial for the small famers (Hegde, 1995). The villagers collect the seed from the neem tree situated on the bunds of their farmland (agroforestry) and sale to earn the money, by this way they can also meet the increasing demand of Neem seed for industrial purpose which makes it suitable for agroforestry systems. Growing demand of industries has rejuvenated the neem based agroforestry system in India, as India is rich in neem trees heritage.

On commercial scale various neem products are also exported to western countries which earned the foreign exchange for economy of India.. It has also observed that the presence of $3 / 4$ acres neem tree on farm land keeps the crop free from insects as it has got the insecticidal properties, therefore there is no need to apply any insecticide to protect your agricultural crop from insect and pathogens. There are various neem based agroforestry systems are observed in India as under agri-silviculture, agri-silvi-horticulture, silvipastoral system and shelter belts/wind breaks etc. In traditional agri-silviculture system, retaining tree on farm land with agriculture crop is well known practice in all across the India. neem tree on agriculture land is found everywhere sometimes in farm boundaries or in scattered form on different parts of farm land. In central India Neem is observed to be grown with crop like sorghum, black gram, wheat, chickpea etc. as multipurpose tree. Solanki et al. (1998) planted Neem on farm boundary has observed no any harmful effect on wheat productivity, and only $4.1 \%$ effects have seen in the production of wheat while Acacia nilotica and Dalbergia sisso retarded the wheat crop significantly. Puri and Bangarwa (1992) observed that Neem tree reduces the competition for soil moisture between the tree and crop. Pandey et al., 2010 studied eight year old Neem plantation with understory crop black gram (Vigna mungo). Though black gram yield under the tree shade reduced but there was increase in the wood volume and fruit yield of neem trees. But the overall economic return for neem and black gram combination was higher. The study was conducted at National Research Centre for Agroforestry, Jhansi. In a study conducted by Faruk et al., 2008, performance of sunflower in Neem based road side agroforestry system has been calculated and found that the productivity parameters (Seed weight, seed yield, etc) of sunflower was not significantly affected by the interaction effect among tree, cow dung and irrigation treatment combination. Sunflower with Neem and Melia dubia was also studied/reported by (Panneer Selvem, 2003). He reported that sole sunflower performance was better the sunflower with neem. Neem compared with favourably agroforestry species such as Leucaena leucocephala, Albizzia lebbeck and Acacia species due to the high nutrient content of the leaves and the appropriate decomposition rates. In the tropical plains the agri-silvi-horticulture system of Neem is found in association of crop like groundnut, pearl millet, cotton, sorghum, horsegram, mung bean, cowpea, and vegetables (Kumar, 1999).

A study conducted by Indian Agricultural Research Institute, New Delhi during 1960 observed that neem contains variety of chemicals which are multipurpose in nature. The bark of this tree contains 12 to $14 \%$ tannins which are used in many industries. Neem oil is also used in medicines, insecticides and making cosmetics products. Many insect repellent are prepared by oil of neem seed only. In Sahara desert of West Africa, an attempt has been made to plant three rows of neem trees in $250-300 \mathrm{~km}$ of length to reduce the expansion of sand dunes. In January 2015, the government allowed the urea producers to produce up to $100 \%$ of production as neem coated urea. Further, the government made it mandatory to produce at least $75 \%$ of domestic Urea as neem coated and by Spraying urea with neem oil_slows the release of nitrogen, by about 10 to 15 per cent, concomitantly reducing consumption of the fertiliser. Neem reportedly controls more than 200 species of insects, mites and nematode 
worms and major pests such as locusts, rice and maize borers, pulse beetles and rice weevils as it is a collection of biologically active ingredients which insects find it difficult to develop resistance to neem. country's approximately 14 million neem trees annually produce about 0.5 tonnes of fruit, but only 20 per cent of this is collected to extract neem oil for soap-making (Koul et al., 1990) and other pharmaceutical purposes. (http://www.downtoearth.org.in/coverage/neem-coatedgrowth-50413).

Farmers can easily extract the neem seed oil which can be used to guard stored grain against pests and vermin (Jotwani and Sarkar, 1965). Neem is also considered as biological insecticides (Isman, 1997; Vir, 2007). In the past, farmers used to mix neem paste with the mud used to make earthen grain stores and neem powder solution on plants would protect them effectively against caterpillars (Akhtar et al., 2008), grasshoppers (Passerini and Hill, 1993), locusts (Kearney et al., 1994), aphids (Srivastava and Parmar, 1985) and whitefly (Khattak et al., 2006).

Homemade neem extracts though cannot replace commercial pesticides entirely but will certainly reduce their use and promote organic farming. Oil pressed from neem seeds can be used as protein-rich cattle feed (Shukla and Desai, 1988) and poultry feed or made into a nitrogen-rich neem-seed cake which can be applied to soils as a fertilizer. Biological resources are common heritage and are not to be patented, hence farmers can utilise the potential of neem heritage of India to the maximum economic gain. (httpp:// www.downtoearth.org.in /coverage/neem-gains-honouras-indias-wonder-tree-30235).

According to Neem Foundation, India has 22.2 million neem trees, and one tree can produce a minimum of six litres of neem oil. It takes approximately 4 litres of neem oil to coat one tonne of urea. So procuring neem oil for NCU (Neem coated Urea or de-oiled neem cake) isn't a problem, however, lack of appropriate source mechanisms may upset producers initially (http://www.neemfoundation.org /greening-india-withneem/).

Agricultural scientists at the Central Research Institute for Dryland Agriculture (CRIDA), Hyderabad, have recognized neem clones which yield a considerable amount of the chemical Azadirachtin, used as a biocide and in health care products. They developed four neem clones way back in 2004 with required features like faster maturation, high yield of seed and quality wood. The parameters for identifying and selecting the clones were tree form, oil content, and yield of azadirachtin more than 0.4-0.8 per cent. However, plantations raised from a single elite neem clone would be vulnerable to attack by insects which become resistant to Azadirachtin so that the multi-clonal neem plantations/cultivation with other timber species would prevent this in the near future. (http://www.downtoearth.org.in/news/markingneem-24829). India has an estimated 14 million neem trees producing 5 lakh tonnes of seed annually, of which one lakh tonne is utilised by the oil and soap industry. About 20-30 per cent of the rest remains unutilised due to inaccessibility of trees. There are some organisations are doing extension activities like The Neem Mission in Pune, set up by the promoter of neem, and has been trying hard to encourage awareness for the tree and supplies literature, coloured slides, video films and products based on neem.

The recently launched National Agroforestry Policy 2014 focuses on research on native, versatile and multipurpose fast growing tree species. According to the World Agroforestry Center, "the market for neembased pesticides is booming in India-growing by 7 to 9 percent annually-and Europe is expected to be the fastest growing market for the future." Therefore it has the potential to be an important component of sustainable rural development programs. (http://www. worldagroforestry.org/news/wonderful-neem-tree).

\section{Conclusion}

Neem trees provide domestic and marketable products, reduce dependence on outside sources, and diversify the farm, while adding plentiful environmental benefits. Neem could be an important and ideal component of an evolving agroforestry system that farmers can practice in approximately all the regions of India. Neem trees offer numerous profits to the farmers and it can be combined easily with many agricultural crops which wholly gives maximum economic gains. Indian farmers and agriculturists need to scale up the Neem cultivation in agroforestry to develop entrepreneurship and to improve ecological and economical strength of the rural community of the country.

\section{Conflict of interest statement}

Authors declare that they have no conflict of interest. 


\section{References}

Akhtar, Y., Yeoung, Y. R., Isman, M. B., 2008. Comparative bioactivity of selected extracts from Meliaceae and some commercial botanical insecticides against two noctuid caterpillars, Trichoplusia $n i$ and Pseudaletia unipuncta. Phytochem. Rev. 7(1), 77-88.

Blackwell, A., 1997. The Neem Tree Azadirachta indica A. Juss. and Other Meliaceous Plants: Source of Unique Products for Integrated Pest Management, Medicine, Industry and Other Purposes (Ed.: Schmutterer, H.). Weinheim, Federal Republic of Germany: VCH (1995). 716p..

Bohra, B., Sharma, N., Saxena, S., Sabhlok, V., Ramakrishna, Y. B., 2016. Socio-economic impact of biofuel agroforestry systems on smallholder and large-holder farmers in Karnataka, India. Agrofor. Syst. 1-16.

Brandis, D., 1906. Indian Trees. Reprint. International Book Distributers, Dehradun.

Chaturvedi, A.N., 1993. Silviculture in Neem Research and Development (Eds.: Randhawa, N.S., Parmar, B. S.). Society of Pesticide Science, India. pp.38-49.

Chinnamani, S., 1993. Neem Research at ICAR. Genetic Improvement of Neem. Strategies for the Future. pp.11-17.

Chuntanaparb, L., Ranganathan, R.., 1990. Defining tree breeding objectives for multipurpose tree species in Asia (No. 10). Winrock International-F/FRED.

Depommier, D., 2003. The tree behind the forest: ecological and economic importance of traditional agroforestry systems and multiple uses of trees in India. Trop. Ecol. 44(1), 63-71.

Drechsel, P., Glaser, B., Zech, W., 1991. Effect of four multipurpose tree species on soil amelioration during tree fallow in Central Togo. Agrofor. Syst. 16(3), 193-202.

Faruk, M. G., Talucder, M. S. A., Rabbani, M. G. F., Chowdhury, M. A. K., Hossain, M. A., 2008. Performance of sunflower in Neem based road side agroforestry system. J. Agrofor. Environ. 2(1), 1-6.

Girish, K., Shankara Bhat, S., 2008. Neem-a green treasure. Electronic J. Biol. 4(3), 201-111.

Gupta, G. N., 1994. Influence of rain water harvesting and conservation practices on growth and biomass production of Azadirachta indica in the Indian desert. Forest Ecol. Manag. 70(1), 329-339.

Hegde, N. G., 1995. Neem and small farmers: constraints at grassroots level. Ind. Forester. 121(11), 1040-1047.
Isman, M. B., 1997. Neem and other botanical insecticides: barriers to commercialization. Phytoparasitica. 25(4), 339-344.

Isman, M. B., 2004. Factors limiting commercial success of neem insecticides in North America and Western Europe. In: Neem: Today and in the New Millennium. Springer Netherlands. pp.33-41.

Jotwani, M. G., Sircar, P., 1965. Neem seed as a protectant against stored grain pests infesting wheat seed. Ind. J. Entomol. 27(2), 160-164.

Kearney, M. L., Allan, E. J., Hooker, J. E., Mordue, A. J., 1994. Antifeedant effects of in vitro culture extracts of the neem tree, Azadirachta indica against the desert locust (Schistocerca gregaria (Forskål)). Plant Cell Tiss. Organ Cult. 37(1), 67-71.

Khattak, M. K., Mamoon-ur-Rashid, S. A. S., Islam, H. T., 2006. Comparative effect of neem (Azadirachta indica A. Juss) oil, neem seed water extract and Baythroid TM against whitefly, jassids and thrips on cotton. Detail. 1(T6), T7.

Koul, O., Isman, M. B., Ketkar, C. M., 1990. Properties and uses of neem, Azadirachta indica. Can. J. Bot. 68(1), 1-11.

Kumar, B.N., 1999. Agroforestry in the Indian tropics. Ind. J. Agrofor. 1, 47-62.

Kumar, D., 2015. Neem Coated Urea: Uses and Benefits Employment News, New Delhi VOL. XL NO. 15 Pages 6411 - 17 JULY 2015.

Kumar, S. R., Arumugam, T., Anandakumar, C., Balakrishnan, S., Rajavel, D., 2013. Use of plant species in controlling environmental pollution. Bull. Env. Pharmacol. Life Sci. 2, 52-63.

Lokanadhan, S., Muthukrishnan, P., Jeyaraman, S., 2012. Neem products and their agricultural applications. J. Biopest. 5, 72-76.

Luna, R.K., 1996. Plantation Trees. International Book Distributors, Dehradun. 975p.

Mutanal, S. M., Patil, S. J., Shahapurmath, G., 2010. Investigation on the productivity of multipurpose tree species in degraded waste lands. Karnataka J. Agric. Sci. 20(4), 804-806.

Nair, P. R., 1985. Classification of agroforestry systems. Agrofor. Syst. 3(2), 97-128.

Nair, P.K.R., 1979. Agro forestry Research: A retrospective and prospective appraisal. Proc. Int. Conf. International Cooperation in Agro forestry. ICRAF Nairobi. pp.275-296.

Narwal, S. S., Tauro, P., Bisla, S. S., 2003. Neem in Sustainable Agriculture. Scientific Publishers, India.

Pandey, M., Tarafdar, J. C., 2004. Arbuscular mycorrhizal fungal diversity in neem-based 
agroforestry systems in Rajasthan. Appl. Soil Ecol. 26(3), 233-241.

Pandey, A.K., Gupta, V. K., Solanki, K.R., 2010. Productivity of neem-based agroforestry system in semi-arid region of India. Range Mgmt. Agrofor. 31(2), 144-149.

Panneer Selvem, 2003. M. Sc.(Agri.) Thesis, Acharya NG Ranga Agricultural University, Hyderabad.

Passerini, J., Hill, S. B., 1993. Field and laboratory trials using a locally produced neem insecticide against the Sahelian grasshopper, Kraussaria angulifera (Orthoptera: Acrididae), on millet in Mali. Bull. Entomol. Res. 83(01), 121-126.

Puri, S., Bangwara, K.S., 1992. Effect of trees in the irrigated wheat crop in semi arid regions. Agrofor. Syst. 20, 229-241.

Radwanski, S. A., Wickens, G. E., 1981. Vegetative fallows and potential value of the neem tree (Azadirachta indica) in the tropics. Econ. Bot. 35(4), 398-414.

Shukla, P. C., Desai, M. C., 1988. Neem (Azadirachta indica, Juss.) as a source of cattle feed. Int. Tree Crops J. 5(3), 135-142.

Sidhu, D. S., 1995. Neem in agroforestry as a source of plant derived chemicals for pest management. Ind. Forester. 121(11), 1012-1021.

Solanki, K.R., 1998. A decade of research 1988-1998. National Research Centre for Agroforestry, Jhansi, India. pp.26-29.
Srivastava, K. P., Parmar, B. S., 1985. Evaluation of neem oil emulsifiable concentrate against sorghum aphids. Neem Newslett. 2(1), 7.

Troup, R.S., 1921. Siviculture of Indian Trees. Clarendon Press, Oxford.

Vir, S., 2007. Neem genetic diversity in India and its use as biopesticide and biofertilizer. Ind. J. Plant Prot. 35(2), 185-193.

Zypman, S., Ziv, M., Applebaum, S., 1996. Tissue culture methods and cloning of the neem tree (Azadirachta indica) for bioinsecticide production. In: III International Symposium on In Vitro Culture and Horticultural Breeding 447. pp.235-236.

\section{Websites:}

http://www.downtoearth.org.in/coverage/neem-coatedgrowth-50413

http://www.downtoearth.org.in/news/back-where-itbelongs- 18243

http://www.downtoearth.org.in/news/marking-neem24829

http://www.neemfoundation.org/greening-india-withneem/

http://www.worldagroforestry.org/news/wonderfulneem-tree

httpp://www.downtoearth.org.in/coverage/neem-gainshonour-as-indias-wonder-tree-30235

https://foodtank.com/news/2014/04/prized-worldwidethe-neem-tree-finds-a-niche-around-the-world/

\section{How to cite this article:}

Bijalwan, A., Dobriyal, M. J. R., Thakur, T. K., Verma, P., Singh, S., 2017. Scaling-up of neem (Azadirachta indica A. Juss) cultivation in agroforestry for entrepreneurship and economic strengthening of rural community of India. Int. J. Curr. Res. Biosci. Plant Biol. 4(1), 113-118. doi: http://dx.doi.org/10.20546/ijcrbp.2017.401.014 